\title{
Variance in spermatozoa number among Apis dorsata drones and among Apis mellifera drones ${ }^{1}$
}

\author{
Gudrun KoENIGER ${ }^{a *}$, Nikolaus KoENIGER ${ }^{\mathrm{a}}$, Salim TINGEK ${ }^{\mathrm{b}}$, \\ Mananya PHIANCHAROEN ${ }^{\mathrm{c}}$ \\ a Institut für Bienenkunde (Polytechnische Gesellschaft), Faculty of Biology and Informatics, J.W. Goethe \\ University Frankfurt am Main, Karl-von-Frisch-Weg 2, 61440 Oberursel, Germany \\ b ARS Tenom, 8898 Tenom, Sabah, Malaysia \\ c Chulalongkorn University, Faculty of Science, Department of Biology, Bee Biology Res. Unit, Bangkok 10330, \\ Thailand
}

\author{
Received 29 Mars 2004 - Revised 14 May 2004 - Accepted 24 May 2004
}

Published online 1 June 2005

\begin{abstract}
Published estimates of the mean spermatozoa numbers for Apis dorsata drones vary from $1.2 \times$ $10^{6}$ and $2.4 \times 10^{6}$; the number of spermatozoa per individual drone vary from $0.22 \times 10^{6}$ to $2.65 \times 10^{6}$. Counts presented here revealed $1.19 \times 10^{6} \pm 0.25 \times 10^{6}$ spermatozoa in drones sampled near a colony and $1.59 \times 10^{6} \pm 0.18 \times 10^{6}$ in drones sampled at a drone congregation area (DCA) in Sabah, Borneo. The difference between the two sites is significant. Further, the degree of variation in sperm numbers among drones near the colonies was higher than at the DCA. Possible reasons are discussed for spermatozoa number variation between drone samples in A. dorsata and in A. mellifera (published estimates). Furthermore, it is discussed if differences in spermatozoa numbers among fathering males may contribute to differences in patriline proportions within colonies.
\end{abstract}

variation in sperm number / individual drone / Apis dorsata / Apis mellifera / average

\section{INTRODUCTION}

In 1990 Koeniger et al. published the number of spermatozoa obtained from the vesiculae seminales of five Apis dorsata Fabricius drones, captured in Peninsular Malaysia. The average number of spermatozoa per drone was $2.4 \times 10^{6}$. Later, Tan et al. $(1996,1999)$ caught in Vietnam 31 flying drones near a colony and counted only $1.24 \times 10^{6} \pm 0.39 \times 10^{6}$ spermatozoa per drone. In addition he counted spermatozoa from each of 55 drones aged from 12 to 24 days and found an average of $1.15 \times$ $10^{6} \pm 0.49 \times 10^{6}$ (Tan et al., 1996). Woyke et al. (2001) measured an average ejaculate volume of $0.2 \mu \mathrm{L}$ in A. dorsata drones in Nepal. Assuming the same average concentration of
$7.7 \times 10^{6}$ spermatozoa per $\mu$ l as in A. mellifera drones (Woyke, 1960) he suggested that the number of spermatozoa in $A$. dorsata should be closer to $1.2 \times 10^{6}$ than to $2.4 \times 10^{6}$. Calculation of Woyke's data shows 1.54 million spermatozoa.

Sperm numbers are biological data which are taken as a basis to understand several aspects of honey bee mating biology, including drone fitness, polyandry and sperm competition. So we wanted to verify the discrepancies in the number of spermatozoa and collected new samples of $A$. dorsata drones. Further, we include and discuss published data on number of spermatozoa in Apis mellifera L. drones which also exhibit a great variance in average sperm numbers $\left(4.0 \times 10^{6}\right.$ to $11.9 \times 10^{6}$, Tab. IB $)$.

\footnotetext{
* Corresponding author: Gudrun.Koeniger@em.uni-frankfurt.de

${ }^{1}$ Manuscript editor: Stan Schneider
} 
Table I. Number of spermatozoa published by different authors from different regions.

A. Apis dorsata

\begin{tabular}{cccc}
\hline author & origin of sample & $\mathrm{n}$ spermatozoa \\
& & $\mathrm{n}$ drones & \\
\hline Tan et al. (1996) & south Vietnam & $1.24 \pm 0.39$ & 31 \\
Tan et al. (1996) & (captured near colony) & $\min 0.20 / \max 2.00$ & 55 \\
& south Vietnam & $1.15 \pm 0.49$ & \\
Koeniger et al. (1990) & (collected from colony) & $\min 0.13 / \max 2.65$ & 5 \\
& Malaysian Peninsula & $2.46 \pm 0.15$ & \\
present study & (collected from colony) & $\min 2.24 / \max 2.64$ & \\
& Sabah, Malaysia & $1.19 \pm 0.25$ & \\
present study & (captured at colony) & $\min 0.85 / \max 1.67$ & 25 \\
& Sabah, Malaysia & $1.59 \pm 0.18$ & \\
\hline
\end{tabular}

B. Apis mellifera

\begin{tabular}{|c|c|c|c|}
\hline author & origin of sample & A. mellifera race & $\begin{array}{l}\text { sperm number } \\
\left(\times 10^{6}\right)\end{array}$ \\
\hline Woyke (1960) & Poland & A. m. mellifera? & $11-12$ \\
\hline Rinderer et al. (1985) & Venezuela & European $A . m$. & $\begin{array}{c}11.4 \\
(5.7 \pm 0.9 \text { per sem. vesicle })\end{array}$ \\
\hline Rinderer et al. (1985) & Venezuela & Africanized $A . m$. & $\begin{array}{c}9.2 \\
(4.6 \pm 0.9 \text { per sem. vesicle })\end{array}$ \\
\hline Rinderer et al. (1999) & USA, Baton Rouge & European $A . m$. & $\begin{array}{c}8.6 \\
(4.3 \pm 0.42 \text { per sem. vesicle })\end{array}$ \\
\hline Rinderer et al. (1999) & USA, Baton Rouge & European $A . m$. & $\begin{array}{c}4.0 \\
(2.0 \pm 0.1 \text { per sem. vesicle })\end{array}$ \\
\hline Elbassiouny (1992) & Germany, Oberursel & A. m. carnica & $\begin{array}{c}10.2 \pm 0.3 \\
\min 8.1 / \max 12.4\end{array}$ \\
\hline Moritz (1981) & Germany, Oberursel & A. m. carnica & 8.5 \\
\hline Berg $(1990,1992)$ & Germany, Oberursel & A. m. carnica & $\begin{array}{c}7.1 \pm 1.9 \\
\min 3.9 / \max 11.7\end{array}$ \\
\hline Phiancharoen (2004) & Germany, Oberursel & A. m. carnica & $7.6 \pm 1.5$ \\
\hline Koeniger 2002 unpubl. & Germany, Oberursel & A. m. carnica & $8.3 \pm 1.1$ \\
\hline Schlüns et al. (2003) & Germany, Celle & $\begin{array}{l}\text { A. m. carnica } \\
\text { Large drones } \\
\text { Small drones }\end{array}$ & $\begin{array}{c}11.9 \pm 1.0 \\
7.5 \pm 0.5 \\
\min 1.1 / \max 30.3\end{array}$ \\
\hline
\end{tabular}

\section{MATERIALS AND METHODS}

In Tenom, Sabah on Borneo we caught two different samples of drones during the drone flight time between 1830 to $1900 \mathrm{~h}$ local time. One sample of drones from one colony was caught with an insect net nearby the comb which hung at a height of about
$4 \mathrm{~m}$. The other sample of drones was collected over 3 consecutive years (February 2001, 2002 and 2003) at a drone congregation area (DCA) by lifting a queen dummy (a $3.4 \mathrm{~mm}$ piece of black pencil with $1 \mathrm{mg}$ 9OD) to which we had attached a thread coated with insect glue (Koeniger et al., 1994). Drones whose wings got coated by the glue after touching 
the thread dropped to the ground where we collected them.

During dissection of the vesiculae seminales, the endophallus appears either opalescent, which indicates that mucus or sperm had entered, or transparent, which indicates that all spermatozoa remained in the vesiculae seminales. Consequently only spermatozoa of drones with transparent endophalli were counted. In total, the vesiculae seminales of 20 drones with transparent endophalli caught near the colony and of 25 drones with transparent endophalli caught at the DCA could be analyzed. The spermatozoa were dispersed in $0.5 \mathrm{~mL}$ Hyes solution and subsequently killed by adding $4.5 \mathrm{~mL}$ distilled water. They were then counted in a Fuchs-Rosenthal hemocytometer (Koeniger et al., 1990). We counted three samples from the sperm dispersion of each drone. For each sample the spermatozoa were re-dispersed by blowing air through the sample with a pasteur pipette. For each sample we counted 100 units of the counting chamber ( 1 unit = $0.0125 \mathrm{~mm}^{3}$ ). Thus, the number per drone represents the average number of spermatozoa from 300 units.

\section{RESULTS}

The average number of spermatozoa of 20 A. dorsata drones caught near the comb was $1.19 \times 10^{6} \pm 0.25 \times 10^{6}$. The number for individual drones ranged from $0.85 \times 10^{6}$ to $1.67 \times$ $10^{6}$. Twenty five drones caught at the DCA had on average $1.59 \times 10^{6} \pm 0.18 \times 10^{6}$. Individual numbers ranged from $1.33 \times 10^{6}$ to $2.04 \times 10^{6}$ spermatozoa (Tab. I A). The difference in spermatozoa numbers between drones near the colony and those at the DCA was highly significant $(t$-test, $P<0.0001)$. The variation among individual spermatozoa numbers was higher in drones at the colony than at the DCA (Levene test, $P<0.05)$.

\section{DISCUSSION}

The average number of spermatozoa of $A$. dorsata drones sampled near the colony in Sabah were similar to those reported for Vietnam (Tan et al., 1996, 1999), but both numbers were lower than that for drones from a DCA. The lower number, as well as the higher variation of spermatozoa numbers among individual drones sampled at the colony may be explained by the mixture of sexually mature drones starting for the DCA and young drones doing their cleansing and orientation flights. A. mellifera drones start leaving the colony for cleansing and orientation flights when they are only 68 days old (Drescher, 1969). In A. mellifera drones the migration of spermatozoa from the testis into the vesiculae seminales starts at the age of two or three days. There the spermatozoa undergo a second stage of maturation which is finalized at the age from 10 to 12 days. Also in A. dorsata sperm numbers in drones 6-8 days old (about 0.79 million) are lower than in drones aged above 12 days (Tan et al., 1996). The average number of spermatozoa in DCA sampled A. dorsata drones was similar to those calculated from the data of Woyke et al. (2001), who collected ejaculate for instrumental insemination. Ejaculates can only be obtained from sexually mature drones.

As in Tan et al. (1996), the number of spermatozoa in our new samples was lower than the $2.4 \times 10^{6}$ reported for five drones in our original publication (Koeniger et al., 1990). The highest number counted in the present study was $2.04 \times$ $10^{6}$ and in the study of Tan et al. (1996) it was $2.65 \times 10^{6}$. The study of Koeniger et al. (1990) aimed to demonstrate that $A$. dorsata queens mated more than once and was not intended to represent the average number of spermatozoa for drones in A dorsata species.

The range in numbers of Tan et al. (1996) is from 0.2 to $2.00 \times 10^{6}$ in "sexually mature" drones caught near the colony and from 0.22 to $2.65 \times 10^{6}$ in drones aged from 12 to 21 days. The average number of these 55 drones was $1.15 \times 10^{6}$ (Tan et al., 1996). All the drones of known age above 12 days were derived from drone brood of one colony, but they were kept in different nurse colonies after emergence (Tan et al., 1996). As the variation in these drones from the same colony is also high, the differences seem not to be genetic. The variations rather may be due to different environmental conditions during nursing of young drones in different colonies. Kraus et al. (2003) found clear evidence for variability in male mating success at the colony level for A. mellifera.

In the present study numbers of spermatozoa ranged from $0.85 \times 10^{6}$ to $1.67 \times 10^{6}$ in drones caught near the colony and from $1.33 \times 10^{6}$ to $2.04 \times 10^{6}$ in drones sampled at the DCA. The lower variation among individual drones, which have been successful to reach a position 
very near to the queen dummy may suggest that these drones also show a higher fitness in sperm production.

In general, spermatozoa numbers of individual $A$. dorsata and A. mellifera drones show high variance (Tab. IA, B) This could be due to a high error in the method. There are two critical sources for inaccuracy. First, upon dissection some spermatozoa may have been pushed into the endophallus. Second, spermatozoa sink to the bottom and thus there is a gradient of sperm concentration within the solution. Thorough dispersal before taking a sample is crucial. Furthermore, it is possible that not enough counts of a drone sample were done. Normally the number of tested samples per drone or the number of units evaluated are not published, instead only average numbers of spermatozoa are given.

Still we argue that variance in sperm counts is not due solely to experimental error because high inter-drone variance occurs even when spermatozoa are counted by the same person. Similarly to A. dorsata, in A. mellifera differences of more than $100 \%$ in average numbers of spermatozoa have been reported (Tab. IB). Even among drones from one breeder line in Baton Rouge USA or in Oberursel, Germany, numbers of spermatozoa differ from $4.0 \times 10^{6}$ to $8.5 \times 10^{6}$ and $7.6 \times 10^{6}$ to $12 \times 10^{6}$ respectively. In all cited cases spermatozoa of vesiculae seminales of drones aged 11 or 12 day were counted. Schlüns et al. (2003) counted $11.9 \times 10^{6} \pm 1.0 \times 10^{6}$ spermatozoa in drones reared in drone cells. Drones reared in worker cells had an average of $7.5 \times 10^{6} \pm 0.5 \times 10^{6}$. Considering small and large drones the number ranged from one million to 30 million in individual drone correlating to drone size.

Both Apis species, A. dorsata and A. mellifera, have multiple mating and each patriline is present in different percentages within a colony (Moritz et al., 1995; Oldroyd et al., 1996; Palmer and Oldroyd, 2000). Schlüns et al. (2004) found a high correlation between a drone's number of spermatozoa and the percentage of its spermatozoa reaching the spermatheca after instrumental insemination. This suggests that individual differences in number of spermatozoa per drone have an influence on the drone's paternity success. The variance in spermatozoa numbers of $A$. dorsata drones caught at the DCA near the queen dummy was lower compared to the comb sample but still the number varied from $1.33 \times 10^{6}$ to $2.04 \times 10^{6}$. This variance in possibly fathering drones still is sufficient to contribute to differences in patriline proportions within colonies.

Schlüns et al. (2003) demonstrated that the size of $A$. mellifera drones has an influence on its sperm number. In this study spermatozoa numbers range from about one million up to 30 million spermatozoa among drones (aged 12 days) of 10 sister queens. Also in $A$. dorsata the weight of drones varies. The dry weight of $40 \mathrm{~A}$. dorsata drones had a mean and standard deviation of $36.8 \mathrm{mg} \pm 6.2 \mathrm{mg}$ (Radloff et al., 2003). In addition differences in rearing conditions for drone brood due to environmental differences may also influence sperm numbers.

High variance in numbers of spermatozoa even within one subspecies and even within breeder lines in A. mellifera suggest that calculating the number of spermatozoa of drones as a race specific character may be premature. For example in the statement of Kraus et al. (2004) that an $A$. m. capensis drone with $8.9 \times 10^{6} \pm$ $1.1 \times 10^{6}$ (Buys, 1990) has less spermatozoa than $A$. $m$. carnica drone refers arbitrarily only to one of the published sperm numbers: $12.0 \times$ $10^{6} \pm 1 \times 10^{6}$ (Woyke, 1962). Considering the variance of average numbers from 7.5 million to 12 million in $A$. m. carnica drones, $8.9 \times 10^{6}$ falls within the average. Thus it seems difficult to relate sperm numbers to the higher mating frequencies of $A$. m. capensis compared to $A$. $m$. carnica. Their hypothesis of the significance of sperm limitation and evolution of extreme polyandry in honeybees has to be discussed again.

Also, calculating the percentage of spermatozoa that reach the spermatheca as a species specific character must lead to dubious results, as the following example demonstrates: In $A$. dorsata the calculation that between $5-7 \%$ spermatozoa of one drone reach the spermatheca (Koeniger and Koeniger, 2000; Palmer and Oldroyd, 2000) was based on $3.94 \times 10^{6}$ spermatozoa in queens and $2.4 \times 10^{6}$ in drones and the effective paternity of 22.8 (Moritz et al., 1995; Oldroyd et al., 1996). Calculating according to the numbers of Tan et al. (1996) $12.5 \%$ of spermatozoa of one drone reach the spermatheca, according to the data of DCA drones in this report it is $10 \%$. This is about the same amount as calculated for A. cerana $(10 \%)$ 
and A. koschevnikovi (12\%) (Koeniger and Koeniger, 2000; Palmer and Oldroyd, 2000). In any case these results demonstrate that it is premature to draw general conclusions from the differences in number of spermatozoa of Apis drones and that the reason for these variations have to be understood.

Résumé - Variance du nombre de spermatozoïdes chez les mâles d'Apis dorsata et d'Apis mellifera. Ces dernières années des données différentes concernant le nombre moyen de spermatozoïdes par mâle ont été publiées. Les nombres varient entre $1,2 \times 10^{6}$ et $2,4 \times 10^{6}$ (Tab. I), les valeurs individuelles variant entre $0,22 \times 10^{6}$ et $2,65 \times 10^{6}$ (Tan et al. 1996, Tab. IA). A cause de ces écarts élevés, de nouveaux comptages ont été effectués. A l'aide d'un filet 20 mâles ont été capturés au moment du vol des mâles à une faible distance du nid et 25 autres sur un lieu de rassemblement de mâles (LRM). Sur le lieu de rassemblement nous avions attaché sous la fausse reine (leurre) un fil couvert de colle à insecte. Les mâles qui, au cours du vol se collaient les ailes au fil, tombaient au sol et pouvaient être ramassés. Les comptages de spermatozoïdes ont été faits selon le processus habituel : après le montage des vesicula seminalis, les spermatozoïdes ont été rincés dans $0,5 \mathrm{~mL}$ de solution de Ringer, tués en ajoutant 4,5 mL d'eau distillée, puis comptés dans un hémocytomètre. Nous avons obtenu les valeurs suivantes : $1,19 \times 10^{6} \pm 0,25 \times$ $10^{6}$ spermatozoïdes chez les mâles près $\mathrm{du}$ nid et $1,59 \times 10^{6} \pm 0,18 \times 10^{6}$ chez les mâles du LRM. (Tab. IA). La différence entre les deux lieux était hautement significative et la variation interindividuelle du nombre de spermatozoïdes était significativement plus forte chez les mâles proches du nid que chez ceux du LRM.

Les nombres de spermatozoïdes publiés varient fortement, la moyenne se situant entre 4,0 millions et 11,9 millions. Nous discutons les causes possibles de ces différences Il semble improbable qu'elles soient dues à des erreurs méthodologiques, car on trouve aussi des différences du même ordre de grandeur chez le même auteur. C'est avant tout les différences liées au milieu qui sont responsables des variations. La saisonnalité et les conditions de soin des mâles pourraient influencer la maturation des spermatozoïdes et être à l'origine des différences observées. On discute dans quelle mesure le succès reproductif des mâles dépend des différences individuelles du nombre de spermatozoïdes par mâle.

Apis dorsata / Apis mellifera / nombre de spermatozoïdes / variance / mâle

Zusammenfassung - Varianz der Spermatozoenzahl bei Drohnen innerhalb von Apis dorsata und innerhalb von Apis mellifera. In den letzten Jahren wurden für Apis dorsata unterschiedliche Durchschnittszahlen für Spermatozoen pro Drohn veröffentlicht. Die Zahlen variierten von $1,2 \times 10^{6}$ und $2,4 \times 10^{6}$ (Tab. IA); die Einzelwerte für individuelle Drohnen variierten von $0,22 \times 10^{6}$ bis $2,65 \times 10^{6}$ (Tan et al. 1996, Tab. IA). Wegen dieser hohen Diskrepanz wurden noch einmal $A$. dorsata Drohnen für die Zählung der Spermien gefangen, und zwar 20 Drohnen mit einem Insektennetz zur Drohnenflugzeit in kurzem Abstand vom Volk und 25 Drohnen auf dem Drohnensammelplatz (DSP). Auf dem Sammelplatz hatten wir unter der Königinnenattrappe einen Faden mit Insektenkleber gehängt. Drohnen, deren Flügel beim Anflug verklebt wurden, fielen zu Boden und konnten aufgesammelt werden. Die Zählungen erfolgten nach dem üblichen Verfahren - nach der Präparation der Vesicula seminalis wurden die Spermien in $0,5 \mathrm{~mL}$ Insektenringerlösung aufgeschwemmt, mit 4,5 mL destilliertem Wasser abgetötet und im Hämocytometer gezählt. Es ergaben sich folgende Werte: $1,19 \times 10^{6} \pm 0,25 \times 10^{6}$ Spermatozoen bei Drohnen nahe am Volk und 1,59 $\times 10^{6} \pm$ $0,18 \times 10^{6}$ bei Drohnen vom DSP (Tab. IA). Der Unterschied zwischen beiden Plätzen war signifikant, außerdem war der Grad der Variation der Spermienzahlen bei Drohnen in Volksnähe signifikant höher als die der Drohnen vom DSP.

Veröffentlichungen über Spermienzahlen in A. mellifera variieren ebenfalls stark, die Durchschnittszahlen liegen von 4,0 Millionen bis 11,9 Millionen. Wir diskutieren mögliche Ursachen für diese unterschiedlichen Ergebnisse. Es scheint unwahrscheinlich zu sein, dass nur methodische Fehler vorliegen, denn auch bei denselben „Zählern“"(Autoren) finden sich Unterschiede in den Spermienzahlen in etwa dem gleichen Ausmaß. Vielmehr könnten vor allem umweltbedingte Unterschiede vorliegen. Saisonalität und Pflegebedingungen der Drohnen könnten die Spermareifung beeinflussen und damit Unterschiede verursachen. Wir diskutieren, in welchem Maße der reproduktiven Erfolg einzelner Drohnen von unterschiedlichen Spermienzahlen abhängt.

Varianz bei Spermienzahlen / Mittelwerte / Einzeldrohnen / Apis dorsata / Apis mellifera

\section{REFERENCES}

Berg S. (1992) Der Reproduktionserfolg von Drohnen (Apis mellifera L.) unterschiedlicher Größe, $\mathrm{PhD}$ Thesis Johann-Wolfgang Goethe Univ. Frankfurt am Main.

Berg S., Koeniger N. (1990) Larger drones (Apis mellifera) have more offspring, in: Proc. German Zoological Society, 83rd Meeting, Frankfurt am Main, Gustav Fischer Verlag, p. 614.

Buys B. (1990) Features of basic reproduction in drones and queens of the Cape honeybee Apis 
mellifera capensis, in: Anderson R.H., Buys B. (Eds.), Proc. Int. Beekeepers' Symp.: Bees and beekeeping in Southern Africa, Posa \& WPBA, Cape Town, pp. 106-109.

Drescher W.(1969) Die Flugaktivität von Drohnen der Rasse Apis mellifera carnica und Apis mellifera ligustica L. in Abhängigkeit von Lebensalter und Witterung, Z. Bienenforsch. 9, 390-409.

Elbassiouny A.M.M. (1992) Comparative studies on the carniolan honey bee race and its crosses, $\mathrm{PhD}$ Thesis, Dept. Plant Protection, Fac. Agriculture, Ain Shams Univ., Alexandria, Egypt, p. 53.

Koeniger N., Koeniger G. (2000) Reproductive isolation among species of the genus Apis, Apidologie 31, 313-339.

Koeniger G., Koeniger N., Mardan M., Punchihewa R.W.K., Otis G.W. (1990) Numbers of spermatozoa in queens and drones indicate multiple mating in Apis andreniformis and Apis dorsata, Apidologie 21, 281-286.

Koeniger N., Koeniger G., Tingek S., Kelitu A., Mardan M. (1994) Drones of Apis dorsata (Fabricius, 1793) congregate under the canopy of tall emergent trees in Borneo, Apidologie 25, 249-264.

Kraus F.B., Neumann P., Scharpenberg H., van Praagh J., Moritz R.F.A. (2003) Male fitness of honeybee colonies (A. mellifera L.), J. Evol. Biol. 16, 914-920.

Kraus F.B., Neumann P., van Praagh J., Moritz R.F.A. (2004) Sperm limitation and the evolution of extreme polyandry in honeybees (Apis mellifera L.), Behav. Ecol. Sociobiol. 55, 494-501.

Moritz R.F.A. (1981) Der Einfluss der Inzucht auf die Fitness der Drohnen von Apis mellifera carnica, Apidologie 12, 41-55.

Moritz R.F.A., Kryger P., Koeniger G., Koeniger N., Estoup A., Tingek S. (1995) High degree of polyandry in Apis dorsata queens detected by DNA microsatellite variability, Behav. Ecol. Sociobiol. 37, 357-363.

Oldroyd B.P., Smolenski A.J., Cornuet J.-M., Wongsiri S., Estoup A., Rinderer T.E., Crozier R.H. (1996) Levels of polyandry and intracolonial genetic relationships in Apis dorsata (Hymenoptera: Apidae), Ann. Entomol. Soc. Am. $89,276-283$
Palmer K.A., Oldroyd B.P. (2000) Evolution of multiple mating in the genus Apis, Apidologie 31, 235-248.

Phiancharoen M. (2004) Instrumental insemination and reproductive incompatibility in the genus Apis in Thailand, PhD Thesis, Fac. Science, Dept. Biology, Bee Biology Research Unit, Bangkok 10330, Thailand.

Radloff S.E., Hepburn H.R., Koeniger G. (2003) Comparison of flight design of Asian honeybee drones, Apidologie 34, 353-358.

Rinderer T.E., Collins A.M., Pesante D. (1985) A comparison of Africanized and European drones: weights, mucus gland and seminal vesicle weights, and counts of spermatozoa, Apidologie 16, 407-412.

Rinderer T.E., de Guzman L.I., Lancaster V.A., Delatte G.T., Stelzer J.A. (1999) Varroa in the mating yard: The effect of Varroa jacobsoni and Apistan on drone honey bees, Am. Bee J. 139, 134-139.

Schlüns H., Schlüns E.A., van Praagh J., Moritz R.F.A. (2003) Sperm numbers in drone honeybees (Apis mellifera) depend on body size, Apidologie 34, 577-584.

Schlüns H., Koeniger G., Koeniger N., Moritz R.F.A. (2004) Sperm utilization pattern in the honeybee (A. mellifera L.), Behav. Ecol. Sociobiol. 56, 458-463.

Tan N.Q., Mardan M., Thai P.H., Chinh P.H. (1996) Some reproductive biology of Apis dorsata, in: Matsuka M., Tam D.Q., Enomoto H., Dap N.T. Trung L.Q., Dau T.T., Niem N.V., Hang N.T., Chinh P.H. (Eds.), Proc. 3rd AAA Conf. on Bee Research and Beekeeping Development, Hanoi 2001, pp. 15-22.

Tan N.Q., Mardan M., Thai P.H., Chinh P.H.(1999) Observation on multiple mating flights of Apis dorsata queens, Apidologie 30, 339-346.

Woyke J. (1960) Natural and artificial insemination of queen honey bees, Pszcz. Zesz. Nauk. 4, 183275.

Woyke J. (1962) Natural and artificial insemination of queen honey bees, Bee World 43, 21-25.

Woyke J., Wilde J., Wilde M. (2001) Apis dorsata drone flights, collection of semen from everted endophalli and instrumental insemination of queens, Apidologie 32, 407-416. 